\title{
Dissolved fluoride removal by OCP, a precursor of apatite
}

\author{
Alfredo Idini $^{1}$, Elisabetta Dore $^{1}$, Dario Fancello ${ }^{1}$, Giorgio Ghiglieri ${ }^{1}$, and Franco Frau ${ }^{1, *}$ \\ ${ }^{1}$ Department of Chemical and Geological Sciences, University of Cagliari, 09042 Monserrato (CA), \\ Italy
}

\begin{abstract}
The consumption of water with fluoride concentration higher than $1.5 \mathrm{mg} / \mathrm{L}$ (WHO recommended limit) is recognized to cause serious diseases. Fluoride removal from natural contaminated waters is a worldwide priority for more than 200 million people. The octacalcium phosphate (OCP), a mineralogical precursor of bio-apatite, is here tested as a fluoride remover. A new two-step method for the synthesis of OCP is proposed; it consists of 1) synthesis of brushite from calcium carbonate and phosphoric acid and, 2) subsequent hydrolysis of brushite. Fluoride removal experiments were performed in batch-mode using $200 \mathrm{mg}$ of OCP in $50 \mathrm{ml}$ solutions with different initial concentrations of fluoride (from 40 to $140 \mathrm{mg} / \mathrm{L}$ ). Most of fluoride is removed within the first two hours, whereas the WHO limit of $1.5 \mathrm{mg} / \mathrm{L}$ is reached within a minimum of 3 hours for a starting $\mathrm{F}^{-}$concentration of $40 \mathrm{mg} / \mathrm{L}$, and in about 12 hours for a starting F-concentration of $80 \mathrm{mg} / \mathrm{L}$. One gram of OCP can remove up to $26 \mathrm{mg}$ of fluoride. The $\mathrm{pH}$ of the solution after the treatment is within the range of drinking water. XRD characterization of the solid phases, before and after the experiments, indicates that OCP transforms into fluorapatite via $\mathrm{F}^{-}$removal from solution.
\end{abstract}

\section{Introduction}

Fluorine is considered an essential micronutrient for human health as fluoride $\left(\mathrm{F}^{-}\right)$. However, if consumed in high amounts for a long time, fluoride can cause serious health problems, such as dental and skeletal fluorosis, birth defects and neurological disorders. The WHO (World Health Organization) set at $1.5 \mathrm{mg} / \mathrm{L}$ the $\mathrm{F}^{-}$concentration for drinking water [1]. The usual consumption of water with high $\mathrm{F}^{-}$concentration is a global concern affecting millions of people living in the East African Rift Valley (EARV) [2]. This research is part of the FLOWERED project, a HORIZON2020 project, aimed at developing a defluoridation method for drinking water suitable for the rural areas of EARV; the method should be low-cost, easy-to-use, effective and free of collateral effects on treated water.

The inorganic part of animal and human bones and teeth consists of hydroxylapatite (HAP) but, in the presence of high $\mathrm{F}^{-}$exposure, the $\mathrm{F}^{-}$can be accumulated into the hard tissue by means of the formation of fluorapatite (FAP) instead of hydroxylapatite [3].

\footnotetext{
*Corresponding author : frauf@unica.it
} 
Taking into account that the octacalcium phosphate (OCP) is the precursor of bio-apatite [4], in this work the OCP has been tested for the $\mathrm{F}^{-}$removal from solution, with the aim of replicating the natural mechanism of $\mathrm{F}^{-}$absorption occurring in the human body.

\section{Experimental}

\subsection{Synthesis of sorbent}

All the reagents used were of analytical grade (Carlo Erba reagents ACS-for analysis). The synthetic OCP was obtained through a two-step synthesis method: firstly, synthetic brushite (DCPD, dicalcium phosphate dihydrate) was synthesized at room temperature by adding appropriate quantities of $\mathrm{H}_{3} \mathrm{PO}_{4}$ and $\mathrm{CaCO}_{3}$, in order to have a molar ratio $\mathrm{Ca} / \mathrm{P}=1$, in ultrapure water (Millipore, Milli- $\mathrm{Q}^{\circledR}, 18.2 \mathrm{M} \Omega \mathrm{cm}$ ) acidified with $\mathrm{HCl}$. After precipitation the DCPD was recovered through filtration and dried at $40{ }^{\circ} \mathrm{C}$. During the second step, the OCP was obtained from the DCPD hydrolysis: $1.2 \mathrm{~g}$ of synthetic DCPD was added to 500 $\mathrm{ml}$ of ultrapure water, with starting $\mathrm{pH}=7.2$, and heated at $60{ }^{\circ} \mathrm{C}$ for 65 hours. At the end of the reaction, the OCP was recovered through filtration and dried at room temperature.

\subsection{Sorption experiments}

The fluoride solutions for the sorption experiments were prepared dissolving appropriate amounts of $\mathrm{NaF}$ in ultrapure water.

The experiments were performed in batch-mode using $50 \mathrm{ml}$ conical flasks agitated through a rotor system (40 rpm), at room temperature: $200 \mathrm{mg}$ of OCP were added to $50 \mathrm{ml}$ of solutions with different initial $\mathrm{F}^{-}$concentrations $(40,60,80,120,140 \mathrm{mg} / \mathrm{L})$, for different times of reaction (from $0.5 \mathrm{~h}$ to $21 \mathrm{~h}$ ). The solution $\mathrm{pH}$ was measured before and after the experiments. At the end of each experiment the solid and the solution were separated through filtration and recovered to carry out the mineralogical characterization and chemical analysis.

\subsection{Chemical analysis and mineralogical characterization}

The $\mathrm{F}^{-}$concentration in solution before and after the experiments was determined by a potentiometer (sensION ${ }^{\mathrm{TM}}+\mathrm{MM} 340, H A C H$ LANGE) with an Ion Selective Fluoride Electrode (ISE F- 9655C, HACH LANGE). To buffer the $\mathrm{pH}$ of solutions and avoid the possible interference of metallic complexes during the $\mathrm{F}^{-}$analyses, the TISAB III solution (Total Ionic Strength Adjustment Buffer, concentrated for $\mathrm{F}^{-}$analyses, $H A C H$ ) was added in the recommended volume ratio 1:5 between TISAB III and standard or sample solutions.

The mineralogical characterization of DCPD and OCP, before and after the experiments, was performed by collecting XRD patterns in the $5-55^{\circ} 2 \theta$ angular range on an automated PANalytical X'pert Pro diffractometer, with Ni-filtered $\mathrm{Cu} \mathrm{K}_{\alpha 1}$ radiation $(\lambda=$ $1.54060 \AA$ ), operating at $40 \mathrm{kV}$ and $40 \mathrm{~mA}$, using the $\mathrm{X}^{\prime}$ Celerator detector.

\section{Results and discussion}

\subsection{Synthesis}

The XRD pattern of the synthetic phase obtained from the first step of the synthesis reaction (Fig. 1A) shows peaks ascribable at DCPD, and the pattern of the product of 
DCPD hydrolysis (Fig. 1B) is attributable at OCP. In both cases, peaks of secondary phases are not present.

The reaction of DCPD precipitation from aqueous solution and its hydrolysis into OCP can be summarized, respectively, by the reactions (1) and (2):

$$
\begin{gathered}
\mathrm{CaCO}_{3}+\mathrm{H}_{3} \mathrm{PO}_{4}+2 \mathrm{H}_{2} \mathrm{O} \rightarrow \mathrm{CaHPO}_{4} \cdot 2 \mathrm{H}_{2} \mathrm{O}_{D C P D}+\mathrm{CO}_{2}+\mathrm{H}_{2} \mathrm{O} \\
\mathrm{CaHPO}_{4} \cdot 2 \mathrm{H}_{2} \mathrm{O} \leftrightarrow 0.125 \mathrm{Ca}\left(\mathrm{HPO}_{4}\right)_{2}\left(\mathrm{PO}_{4}\right)_{4} \cdot 5 \mathrm{H}_{2} \mathrm{O} o C P+0.25 \mathrm{HPO}_{4}{ }^{2-}+1.375 \mathrm{H}_{2} \mathrm{O}+0.5 \mathrm{H}^{+}
\end{gathered}
$$

The reaction (2), obtained with $1.2 \mathrm{~g}$ of DCPD in $500 \mathrm{ml}$ of ultrapure water, leads to decreasing the solution $\mathrm{pH}$ from 7.2 to 4.9 .

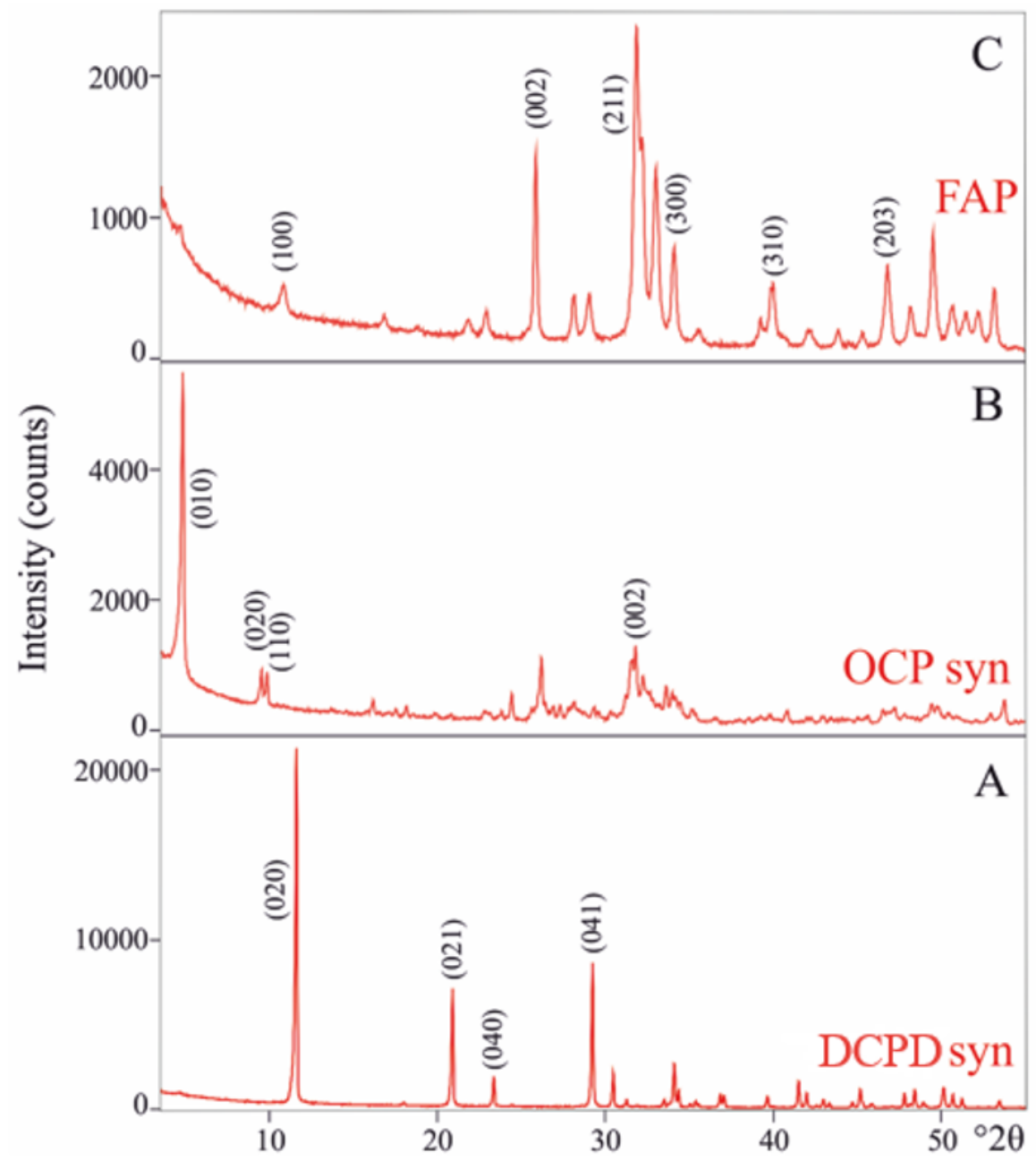

Fig. 1. XRD patterns of A) synthetic DCPD (ICDD reference pattern used for identification was n. 00-009-0077); B) synthetic OCP (ICDD reference pattern n. 00-026-1056); C) the representative sample recovered after the $\mathrm{F}^{-}$removal experiment with initial $\mathrm{F}^{-}$concentration of $140 \mathrm{mg} / \mathrm{L}$ showing the formation of fluorapatite (ICDD reference pattern n. 00-015-0876). 


\subsection{Fluoride removal experiments}

In all experiments, most of dissolved $\mathrm{F}^{-}$is removed from solution during the first hours after the addition of OCP, then the $\mathrm{F}^{-}$concentration in solution decreases slowly (Fig. 2). The time required to reach the $\mathrm{F}^{-}$equilibrium in solution varies, as a function of the initial $\mathrm{F}^{-}$concentration, from 3 hours $\left(\mathrm{F}^{-}=40 \mathrm{mg} / \mathrm{L}\right)$ to 16 hours $\left(\mathrm{F}^{-}=140 \mathrm{mg} / \mathrm{L}\right)$.

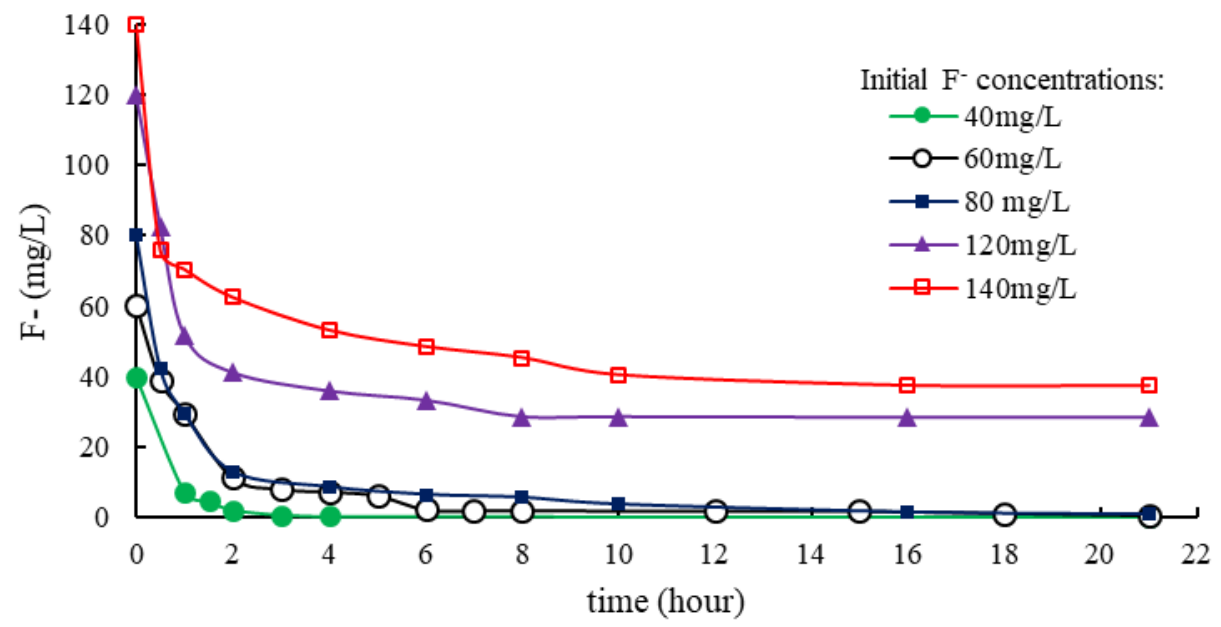

Fig. 2. The $\mathrm{F}^{-}$concentration in solution during the $\mathrm{F}^{-}$removal experiments.

The OCP proves to be a very effective $\mathrm{F}^{-}$remover. In the experiments with starting $\mathrm{F}^{-}$ concentrations equal to 40,60 and $80 \mathrm{mg} / \mathrm{L}$ more than $99 \%$ of $\mathrm{F}^{-}$is removed, whereas the percentage of $\mathrm{F}^{-}$removed reaches $76 \%$ in the experiment with the highest initial $\mathrm{F}^{-}$ concentration (Table 1). Moreover, at the end of the experiments, the overall water quality is unchanged: the solution $\mathrm{pH}$ value slightly decreases, remaining in the range suggested by WHO (6.5 - 9.5) for drinking water.

Table 1. Solution $\mathrm{pH}$ values measured before $(0 \mathrm{~h})$ and after $(21 \mathrm{~h})$ the sorption experiments, and concentration of residual dissolved $\mathrm{F}^{-}$and its percentage removed from solution at the end of the experiments $(21 \mathrm{~h})$.

\begin{tabular}{lcccc}
\hline Experiment & \multicolumn{2}{c}{$\mathrm{pH}$} & $\mathrm{F}^{-}(21 \mathrm{~h})$ & $\mathrm{F}^{-}$removed \\
\hline & $0 \mathrm{~h}$ & $21 \mathrm{~h}$ & $\mathrm{mg} / \mathrm{L}$ & $\%$ \\
\hline $\mathrm{F}^{-} 40 \mathrm{mg} / \mathrm{L}$ & 8 & 6.52 & 0.03 & 99.9 \\
$\mathrm{~F}^{-} 60 \mathrm{mg} / \mathrm{L}$ & 8 & 6.62 & 0.53 & 99.1 \\
$\mathrm{~F}^{-} 80 \mathrm{mg} / \mathrm{L}$ & 8 & 6.72 & 0.71 & 99.1 \\
$\mathrm{~F}^{-} 120 \mathrm{mg} / \mathrm{L}$ & 8 & 6.92 & 28.5 & 76.2 \\
$\mathrm{~F}^{-} 140 \mathrm{mg} / \mathrm{L}$ & 8 & 6.96 & 37.3 & 73.4 \\
\hline
\end{tabular}

The results suggest that the OCP, in the presence of dissolved $\mathrm{F}^{-}$, is very unstable and tends to transform into fluorapatite (FAP); this is supported by mineralogical XRD analysis of representative samples: the characteristic peaks (010), (020) and (110) of synthetic OCP (Fig. 1B) are no longer detectable in the solid recovered at the end of the experiment performed with an initial $\mathrm{F}^{-}$concentration of $140 \mathrm{mg} / \mathrm{L}$, whereas the most intense peaks (002) and (211) of FAP clearly appear (Fig. 1C). The $\mathrm{F}^{-}$removal process can be represented by the reaction (3): 


$$
\mathrm{Ca} 8\left(\mathrm{HPO}_{4}\right)_{2}\left(\mathrm{PO}_{4}\right)_{4} \cdot 5 \mathrm{H}_{2} \mathrm{O} O C P+1.6 \mathrm{~F}^{-} \rightarrow 1.6 \mathrm{Ca}_{5}\left(\mathrm{PO}_{4}\right)_{3} \mathrm{~F}_{F A P}+1.2 \mathrm{HPO}_{4}{ }^{2-}+5 \mathrm{H}_{2} \mathrm{O}+0.8 \mathrm{H}^{+}
$$

On the basis of the stoichiometry of reaction (3), 1 gram of OCP can remove up to 29.4 $\mathrm{mg}$ of $\mathrm{F}^{-}$. The maximum empirical $\mathrm{F}^{-}$removal capacity of OCP obtained from sorption experiments is $25.7 \mathrm{mg} / \mathrm{g}$, confirming the good potential use of OCP for water defluoridation and indicating that OCP is more effective than synthetic hydroxylapatite (HAP) and synthetic brushite (DCPD) for water defluoridation [5].

\section{Conclusion and further development}

In this work, synthetic octacalcium phosphate (OCP), a precursor of fluorapatite (FAP), was tested for water defluoridation. Results obtained from batch $\mathrm{F}^{-}$sorption experiments are promising and encourage further investigations. The OCP is unstable in solution and in the presence of dissolved $\mathrm{F}^{-}$tends to transform into FAP. The maximum empirical sorption capacity measured is $25.7 \mathrm{mg} \mathrm{F}^{-}$for $1 \mathrm{~g}$ of OCP, very close to the maximum theoretical stoichiometric capacity $(29.4 \mathrm{mg} / \mathrm{g})$. In addition, the defluoridation with OCP does not affect the overall quality of water; indeed, during the removal reaction, the solution $\mathrm{pH}$ slightly decreases, remaining in the range suggested by WHO for drinking water. Further studies should be addressed to evaluate the effect of coexistent anions on the $\mathrm{F}^{-}$removal capacity and test the OCP with natural fluoride-rich waters used by the rural communities of the East African Rift Valley for domestic and drinking use. This step will be crucial to assess the real possibility of applying the OCP to water defluoridation in the field as a simple, low-cost, easy-to-use and effective method.

This research was financially supported by FLOWERED project (Coordinator G. Ghiglieri), a Horizon 2020 European funded project (Grant Agreement - N. 690378) (www.floweredproject.org).

\section{References}

1. H. G. Gorchev, G. Ozolins, WHO Chron. 38, 104-108 (2011)

2. K.M.K. Kut, A. Sarswat, A. Srivastava, C.U. Pittman, D.A. Mohan, Groundw. Sustain. Dev. 2-3, 190-212 (2016)

3. E.D. Eanes, A.H. Reddi, Metab. Bone Dis. Relat. Res. 2, 3-10 (1979)

4. R. Xin, Y. Leng, N. Wang, J. Cryst. Growth 289, 339-344 (2006)

5. S.S. Waghmare, T. Arfin, Int. J. Innov. Res. Sci. Eng. Technol. 4, 8090-8102 (2015) 